\title{
Food, Spaces of Consumption and the Exhibition of Taste in Catherine Gore's Silver-
}

\section{Fork Fiction, 1830-1834}

\section{Charlotte Boyce}

Abstract (keywords in bold):

Critics regularly observe that lavish dinner parties constitute one of the formulaic features of silver-fork fiction, but tend to overlook the subtle ideological labour undertaken by such representations. Drawing on sociological theories of taste and distinction, this essay argues that, in the novels of Catherine Gore, items of food and spaces of consumption operate as codified information systems which, by classifying diners, help to police the fragile boundary between exclusive and non-exclusive society. Yet, while ridiculing vulgar social climbers who lack the cultural capital to perform discerningly, Gore also critiques the idea of 'natural' aristocratic distinction by satirizing the arbitrary codes of etiquette and gendered behaviours that signify 'good taste' at table. This demystification of the conventions of fashionable society is accompanied by a tacit endorsement of middle-class domestic values. The ideology of taste that emerges in Gore's fiction is therefore complex and contradictory, working both to reinforce and subvert the cultural authority of the ruling elite.

In an article on Catherine Gore's 1831 novel Pin Money, the Westminster Review urges readers to observe the pains taken by the author 'to shew her familiar acquaintance with parts of a luxurious bill of fare, that we may respect her condition in life as much as her talent for writing ${ }^{1}$. The implication here is that references to food in Gore's novel operate not simply as incidental realist details or textual embellishments but as forms of social currency which highlight the author's intimacy with the minutiae of fashionable life. Just as the meal alluded to in the article works to locate its fictional consumer, Sir Brooke Rawleigh, within a specific habitus, so it classifies its creator, positioning her as an insider to the privileged world of ton. By freighting acts of consumption with cultural meaning in this way, Pin Money demonstrates Roland Barthes' theory that food is never purely a matter of nutritional necessity, never simply the material substance that satisfies our 'first need', but always also a mode of communication, 'a protocol of usages, situations, and behaviour'. Imbricated in a

\footnotetext{
1 ‘Art. IX - Pin Money’, Westminster Review, 15 (1831), 433-42 (p. 438).
} 
complex symbolic system, food 'sums up and transmits a situation; it constitutes an information; it signifies'. ${ }^{2}$

For the Westminster Review, Gore's attention to the dietary choices of her upper-class characters signifies above all that she is 'an adherent of the silver-fork school', a type of novel-writing popular in the 1830 s and distinguished by its focus on the amusements and intrigues of exclusive metropolitan society. ${ }^{3}$ In particular, as the designation 'silver fork' suggests, the genre was notorious for its interest in the rituals of and accoutrements to aristocratic dining. Indeed, according to William Hazlitt (whose disparaging review for the Examiner first inspired the 'silver-fork' moniker), 'provided a few select persons eat fish with silver forks', such fictions deem it 'a circumstance of no consequence if a whole country starves'. Inherent in Hazlitt's critique is the notion that silver-fork novels are interested in social forms above more weighty political or philosophical issues; beguiled by surfaces, fashionable fictions reduce acts of consumption to mere spectacles of affluence, stripping them of any real significance in the process.

Subsequent critics have tended to follow Hazlitt's lead, characterizing opulent dinners as just one of a number of formulaic features to be found in silver-fork novels, the collective purpose of which is to dazzle readers greedy for a vicarious taste of the high life. Such readings typically overlook, however, the subtle ideological labour undertaken by apparently superficial, iterative representations of dining. In Gore's fiction, in particular, details about what, where, when and how characters eat are by no means empty narrative appendages. Rather, via their entanglement in influential discourses of taste and distaste, food, eating and

\footnotetext{
${ }^{2}$ Roland Barthes, 'Toward a Psychosociology of Contemporary Food Consumption', in Food and Culture: A Reader, ed. by Carole Counihan and Penny Van Esterik, 3rd edn (New York and Abingdon: Routledge, 2013), pp. 23-30 (p. 24, my emphasis).

3 'Art. IX - Pin Money', p. 437.

${ }^{4}$ William Hazlitt, 'The Dandy School', Examiner, 18 November 1827, pp. 721-23 (p. 722).
} 
spaces of consumption figure as primary sites for the articulation and subversion of social codes and gendered behaviours, as well as for the negotiation of shifting class relations.

Significantly, the social and political upheavals that characterized the 'age of reform' were often reflected, in microcosm, around the dinner table. William IV's ascension to the throne in June 1830 was marked by the overthrow of the old culinary order in the royal household. According to a diarist of the time, one of the new king's very first acts was to dismiss his predecessor's legion of French cooks; whereas George IV was notorious for his love of decadent feasting, William's tastes were those of 'a country gentleman' and he rejected all 'luxury and magnificence' at table. ${ }^{5}$ This recalibration of royal dining-habits-a kind of downward emulation-was coincident with a drive on the part of the economically empowered middle classes to boost their standing by acquiring the gastronomic knowledge and refined table manners that had traditionally been the preserve of the social elite. ${ }^{6}$ As Elizabeth Langland notes, within the mutable socio-political landscape of reform-era Britain, 'status became a fluid thing, increasingly dependent upon the manipulation of social signs'. Around the dinner table, then, objects and practices of consumption took on a vital cultural importance, functioning as powerful but precarious repositories of meaning, influential but appropriable classificatory signs, which, in their imitability, could work both to shore up and dismantle existing hierarchies.

The texts by Catherine Gore explored in this essay_-The Manners of the Day (1830), Mothers and Daughters (1831), Pin Money (1831), The Hamiltons (1834), and a selection of short stories from The Sketch Book of Fashion (1833) - take a collective interest in the

\footnotetext{
${ }^{5}$ Charles C. F. Greville, The Greville Memoirs: A Journal of the Reigns of King George IV, King William IV and Queen Victoria, 8 vols, ed. by Henry Reeve (Cambridge: Cambridge University Press, 2011), II, p. 6.

${ }^{6}$ Michael Curtin suggests that, following a period of dearth between 1804 and 1828, there was a sudden explosion in the publication of etiquette guides during the $1830 \mathrm{~s}$, as upwardly mobile middle-class readers sought to learn 'aristocratic manners in order to convert their economic success into social prestige'. Curtin, 'A Question of Manners: Status and Gender in Etiquette and Courtesy', The Journal of Modern History, 57 (1985), 395-423 (p. 414).

${ }^{7}$ Elizabeth Langland, Nobody's Angels: Middle-Class Women and Domestic Ideology in Victorian Culture (Ithaca and London: Cornell University Press, 1995), p. 26.
} 
politics and aesthetics of consumption, highlighting and ironizing aristocratic attempts to codify dining behaviours at a time of social flux, as well as bourgeois efforts to emulate that systemized social conduct. Gore's works also elucidate and satirize the ways in which gendered norms of consumption, such as male gourmandism and female abstention, took on heightened significance in the $1830 \mathrm{~s}$, as increased social mobility threatened to undermine traditional class-based epistemologies. The reflexive, self-aware representational strategies that emerge in her fiction ultimately position spaces of consumption-dining-rooms, ballrooms, picnic sites and outdoor fêtes-as ambiguous and permeable bastions of aristocratic prestige. Like the newly crowned William IV, Gore tends to endorse homely values and simple commensality over fashion and gastronomic ostentation, and in this way, this essay argues, her works help to renegotiate nineteenth-century definitions of 'good taste' ${ }^{8}$

\section{Silver Forks and the Politics of Taste}

Taste - the socially determined power of discrimination so crucial to silver-fork fiction-is never ideologically neutral, as Pierre Bourdieu stresses in his classic sociological study Distinction. The very notion of 'good taste' relies on a demarcation between those who have it and those who don't: taste is 'the practical affirmation of an inevitable difference' between 'the possessors of legitimate culture' (that is, the ruling classes) and those whose manifested preferences are deemed vulgar, uncertain, or excessive (the proletariat and middle-class parvenus). ${ }^{9}$ The early nineteenth-century dining-room presented manifold opportunities for

\footnotetext{
${ }^{8}$ April Kendra suggests that this emphasis on family values and domestic affections distinguishes Catherine Gore from male contemporaries, such as Edward Bulwer and Benjamin Disraeli, whose silver-fork fiction focuses more on the fashionable figure of the dandy than social and familial relations. See Kendra, 'Gendering the Silver Fork: Catherine Gore and the Society Novel', Women's Writing, 11 (2004), 25-38.

${ }^{9}$ Pierre Bourdieu, Distinction: A Social Critique of the Judgement of Taste, trans. by Richard Nice (London and New York: Routledge, 2010), p. 49.
} 
individuals to make non-verbal claims to discernment, not only via the exhibition of gustatory preferences, but also via their practical and aesthetic relationship to the material markers of distinction that accrued there ${ }^{10}$ Hazlitt's chosen emblem of the fashionable novel - the fork - amply demonstrates the way in which seemingly innocuous items of tableware can operate as covert repositories of cultural value. In his history of the civilizing process, Norbert Elias notes that the espousal of the fork as eating implement in western society was concomitant with the development of a certain 'standard of delicacy', or taste. Whereas in the middle ages eating with one's fingers constituted acceptable practice, in modernity such behaviour was deemed distasteful. The fork, then, became 'the embodiment of a specific standard of emotions and a specific level of revulsion', a kind of prandial barometer for distinguishing between 'civilized' and 'uncivilized' consumers (a distinction that, perhaps unsurprisingly, mapped closely onto class hierarchies). ${ }^{11}$ Later, as the fork shifted from being a piece of finery associated with fashionable exclusives to an everyday item utilized by all, further distinguishing features and gradations of usage emerged to help categorize consumers. The silver forks evoked by Hazlitt are exemplary in this respect. Used by the upper classes to avoid tainting the delicate flavour of dishes consumed during the fish course, silver forks represented an elaboration of the accessories to tasteful dining. Their presence at table worked to classify diners by signalling possession of both aesthetic and gustatory refinement: an appreciation for beautiful objects allied with connoisseurship in matters of the palate. ${ }^{12}$

\footnotetext{
${ }^{10}$ Bourdieu makes a case for connecting gustatory and aesthetic taste, arguing that 'the elementary taste for the flavours of food' is as much a part of the culture of distinction as 'the elaborated taste for the most refined objects'. Bourdieu, p. xxiv.

${ }^{11}$ Norbert Elias, The Civilizing Process: Sociogenetic and Psychogenetic Investigations, trans. by Edmund Jephcott, ed. by Eric Dunning, Johan Goudsblom and Stephen Mennell, rev. edn (Oxford: Blackwell, 2000), pp. 107-08.

12 The author of one nineteenth-century social instruction manual explains, 'Fish must be divided with a silver fork [...] as the acid, which is frequently in fish sauces, produces an unpleasant taste if it comes into contact with the steel knife. [...] Nothing can be more absurd than to see a would-be élégante eating her fish or tart with a steel fork'. A. F., The Ladies' Pocket-Book of Etiquette, 7th edn (London: George Bell, 1840), p. 43.
} 
The silver fork, then, illustrates Bourdieu's point that 'taste is the practical operator of the transmutation of things into distinct and distinctive signs'-signs that took on a new urgency and relevance in the early 1830s, when accelerating social and political changes complicated traditional ways of knowing and reading the world. ${ }^{13}$ As a number of scholars of the silver-fork genre have noted, conventional class boundaries and power relations were increasingly destabilized during this volatile historical period, as the inherited cultural capital of the aristocracy came into conflict with what Gore terms the 'Social Economy' of the newly enfranchised, wealthy middle classes. ${ }^{14}$ During these turbulent times, the discourse of taste accrued new potency owing to its ability to reinforce traditional hierarchies while masking its constructed status and ideological investment in maintaining the status quo. As Bourdieu explains, taste 'naturalizes real differences, converting differences in the mode of acquisition of culture into differences of nature'. ${ }^{15}$ The 'natural' discernment claimed by nineteenthcentury social elites is therefore anything but; 'natural distinction' is an illusion, Bourdieu affirms, 'based on the power of the dominant to impose, by their very existence, a definition of excellence which, being nothing other than their own way of existing, is bound to appear $[\ldots]$ perfectly necessary, absolute and natural' ${ }^{16}$

Within the novels and collected stories analyzed in this essay, spaces of consumption frequently work to reinforce the ideology of 'natural distinction' outlined by Bourdieu. Notably, one of the recurring set-pieces of Gore's writing is the cross-class dinner party, at which the seemingly instinctive refinement of the aristocracy is contrasted with the vulgar tastes of the nouveaux riches. Gore's novels also recirculate gendered assumptions about standards of tasteful behaviour: in keeping with established fictional conventions,

\footnotetext{
13 Bourdieu, p. 170.

${ }^{14}$ Catherine Gore, The Hamiltons: or, Official Life in 1830 (London: Richard Bentley, 1850), p. 189. All subsequent references are to this edition, incorporated in the text with pagination in parentheses.

${ }^{15}$ Bourdieu, p. 61.

${ }^{16}$ Bourdieu, p. 253.
} 
gourmandism is typically the measure of masculine aristocratic distinction in her works, while appetitive delicacy or conscious denial of the demands of the stomach signifies an elevated female sensibility. Yet, despite such apparent participation in and substantiation of prevailing ideologies of tastefulness, Gore's fiction also denaturalizes the processes by which those ideologies are communicated and perpetuated. If 'distinction' manifests itself in the nineteenth century in codified terms - mannered forms of behaviour and stylized interactions with people and things - then Gore's texts engage in a labour of demystification via their self-conscious representation of spaces of consumption as information systems, and the actions that take place within them as culturally scripted performances. By satirically laying bare the routines and rituals, customs and shibboleths of exclusive society, Gore exposes the arbitrary and constructed character of canons of taste and, in doing so, undermines their implicit claims to universality and disinterestedness.

Her works also elucidate the tensions and paradoxes inherent in early nineteenthcentury notions of distinction, pointing to ways in which 'taste' may be positioned variously as innate and acquired; as timeless and as subject to the vagaries of fashion; as the privilege of rank and as a quality of the individual which operates outside of the parameters of class. These semantic contradictions reveal the fragility of 'taste' as a cultural signifier and classificatory tool, and mirror the internal ideological conflicts that trouble Gore's representations of the beau monde. As I argue in the sections that follow, despite their fascination with aristocratic sites of consumption-extravagant dinners, recherché suppers and stylish fêtes champêtre - Gore's novels invariably end up endorsing a value-system that overlaps significantly with bourgeois cultural ideals. Their narrative trajectories typically involve unworldly heroines (who are of 'good' but not noble birth) acquiring a distaste for the frivolity and superficiality of fashionable society and a concomitant proclivity for the simple comforts of home, their valorization of the domestic affirming 'a thoroughly middle- 
class bottom line'. ${ }^{17}$ Thus, while Gore's literary investment in the discriminatory discourse of taste can be read as part of a reactionary effort to protect the power of traditional elites at a time of social and political reform, her novels' collective destabilization of codes of distinction and uncoupling of genuine tastefulness from ideas of fashionability and rank results in an altogether more ambiguous textual politics - one that threatens to delegitimize the cultural authority of the aristocratic world it constructs.

\section{Social Codes and Dining Routines}

One of the most common critical observations made about the silver-fork novel is that its formulaic representation of the aristocratic habitus renders it analogous to the social instruction manuals that proliferated in the 1830 s. Described variously as 'handbooks to the language of the beau monde', 'unofficial hornbooks for social climbers' and 'etiquette guide[s] for the socially aspiring', silver-fork novels have long been understood-and disparaged - as mimetic forms, which reproduce unthinkingly the epistemological systems and behavioural paradigms of tasteful society for the edification of non-exclusives. ${ }^{18}$ Certainly, the reader of silver-fork fiction will be aware of the genre's dependence on a prescriptive set of narrative ingredients (breakfasts, déjeuners, fêtes, visits to Almack's and the opera), the standardized character of which invites comparisons with 'recipes' in a number of nineteenth-century periodicals. ${ }^{19}$ Importantly, though, the silver-fork novel's deployment of routine allusions and iterative structures is not necessarily reductive,

\footnotetext{
${ }^{17}$ Edward Copeland, The Silver Fork Novel: Fashionable Fiction in the Age of Reform (Cambridge: Cambridge University Press, 2012), p. 35.

${ }^{18}$ Alison Adburgham, Silver Fork Society: Fashionable Life and Literature from 1814 to 1840 (London: Constable, 1983), p. 1; Winifred Hughes, 'Silver Fork Writers and Readers: Social Contexts of a Best Seller', NOVEL: A Forum on Fiction, 25.3 (1992), 328-47 (p. 330); Muireann O'Cinneide, Aristocratic Women and the Literary Nation, 1832-1867 (Basingstoke: Palgrave Macmillan, 2008), p. 51.

${ }^{19}$ See, for instance, 'Novels of Fashionable Life', Dublin University Magazine, 12 (1838), 3-39 (p. 5), and

'Literary Recipes: How to Cook up a Fashionable Novel', Punch, 1841, p. 39.
} 
unquestioning or naïve. In Gore's playful reform-era works, narrative patterning and recursive references to social codes are often used in knowing or parodic ways which help to expose the arbitrary and artificial mechanisms by which upper-class hegemony is maintained.

A key strategy by which Gore denaturalizes the customs and rituals of exclusive society is to present them from the perspective of a heroine newly initiated into their mysteries: someone who possesses sufficient social capital to gain admittance into the select world of ton, but who lacks prior knowledge of its intricacies and conventions. This equivocal position is occupied by, among others, the Countess Reppenheim in the 1833 short story 'The Pavilion' from The Sketch Book of Fashion. When her husband the Prussian ambassador is assigned to a new diplomatic position in England, the Countess (an ingenuous woman of simple tastes) finds herself thrust into the fashionable melee of Regency society. Here, her lack of familiarity with the codified operations of the beau monde leaves her vulnerable to the scheming of two cynical fortune-hunters, Lord Clanhenry and Frederick Fitzgerald, who conspire to betray her into committing a series of faux pas for their own amusement.

As the narrator makes clear, the social customs that the Countess encounters on arrival in England are at once enigmatic and all-powerful:

Of all the capitals of Europe London is the place where the forms of society are loosest in definition and strictest in observation. The slightest infraction of the arbitrary code of conventional law is fatal to the convicted culprits; and not the most pitiful little court of ceremonious Germany is half so scrupulous in the exaction of its etiquettes. ${ }^{20}$

The foreign Countess is, of course, unversed in these finely nuanced rules and unspoken expectations; in a sly dig at those who take works of fiction for reliable handbooks to aristocratic society, the narrator notes that her heroine's ideas of English manners and hospitality have been gleaned entirely from the novels of the previous century. With only

\footnotetext{
${ }^{20}$ Catherine Gore, The Sketch Book of Fashion, 3 vols (London: Richard Bentley, 1833), I, pp. 16-17. All subsequent references are to this edition, incorporated in the text with pagination in parentheses.
} 
these wholly inadequate sources and the malign counsel of Clanhenry and Fitzgerald to guide her, the Countess is waylaid into making a series of gaffes and blunders at the various social events to which she is invited. When, for instance, she receives a card requesting her attendance at 'a very small early party' at the Duchess of Keswycke's Brighton residence, she arrives there at eight in the evening, dressed in plain costume as per Clanhenry and Fitzgerald's instructions, only to find herself a gate-crasher at a lavish dinner peopled by expensively attired guests (the 'small early' gathering does not begin until ten) (I, p. 32). 'Vexed and mortified' by this unintentional breach of etiquette, the Countess determines, on receiving an invitation from Lady Grandison a couple of days later, to make her appearance 'between ten and eleven o'clock, radiant with jewels' (I, p. 33). However, when she arrives at the Grandison house, 'nothing could exceed the contemptuous surprise with which she found herself surveyed by the half dozen old women congregated round a solitary whist-table, their chairs and carriages having been already announced for departure' (I, p. 33). News of the Countess's solecisms quickly circulates around Brighton society, rendering her an object of ridicule. The target of Gore's satire, however, is not the naïve outsider but rather the nontransparency of the protocols and vocabulary that surround aristocratic entertainments in the nineteenth century. If the Countess is right to claim that she will never fully understand the workings of exclusive society it is not because she lacks the requisite taste and discrimination, Gore implies, but because the conventions and practices that convey cultural distinction are arbitrary, unperspicuous and therefore inscrutable to those not already in the know.

Whereas the Countess's ignorance of English social codes stems from her non-native status, the majority of Gore's heroines have difficulty navigating the complex signifying systems of the fashionable world because of their youth and inexperience. Helen Mordaunt, the eighteen-year-old protagonist of The Manners of the Day, is exemplary in this respect. 
Born into a respectable but non-aristocratic family, of ancient bloodline but 'equivocal ton', Helen has little knowledge of elite metropolitan society prior to her marriage to the leading politician Lord Willersdale, a man of 'exquisite taste' and elevated standing, whose public position obliges him to take an active role in the proceedings of the beau monde. ${ }^{21}$ Helen quickly perceives that, as Willersdale's wife, she will be expected to assimilate herself into her husband's milieu and acquit herself with distinction on social occasions. While recognizing that 'there is a science of fashion, an art of hospitality to be acquired in London', she fears that she lacks the cultural competence to master its intricacies: 'unprepared by a key to the cypher, uninitiated into the mysteries of the jargon of fashion, its dialogues seemed spoken in an unknown tongue' (I, pp. 40, 75). The narrator's use of the language of encryption and mystification here is significant: by representing Helen's feelings of bewilderment in such terms, Gore draws attention to the opacity of aristocratic social codes and the consequent aura of imperviousness by which they are surrounded.

In spite of Helen's anxieties regarding her proficiency in the public sphere, Willersdale is confident that his new wife's inherent good taste will secure her admittance to the realms of exclusive society, telling her: 'your own natural elegance, the peculiar grace of your demeanour, will attract, and fix, and fascinate to your side, all those who are deserving of your attention' (I, pp. 40-41). Noticeably, though, this discourse of natural distinction segues quickly into the language of acquisition and cultivation when he adds:

[T]he art of representation will become familiar to you, for all women have an instinctive aptitude for its acquirement; and I shall soon hear you laughing at the remembrance of your present timidity, and playing your part in the beau monde. (I, p. 41)

By positioning social refinement as an 'art' - an attribute to be developed rather than something innate-Willersdale inadvertently undermines the ideology of 'natural' taste on

\footnotetext{
${ }^{21}$ Catherine Gore, The Manners of the Day, 3 vols (London: Henry Colburn and Richard Bentley, 1830), I, pp. 65,33 . All subsequent references are to this edition, incorporated in the text with pagination in parentheses.
} 
which his peer-group depends for its cultural influence. His characterization of social interaction as 'performance', meanwhile, hints that 'distinction' is little more than a repository of stylized behaviours which achieve legitimacy through repeated re-enactment rather than any intrinsic relation to 'good taste'.

\section{Performativity and the Mechanics of Ritual}

Notably, references to performance arise regularly in the texts examined in this essay. More than a decade before Thackeray famously portrayed his protagonists as puppets and himself as stage-manager in his satire of the fashionable novel Vanity Fair (1847), Gore was selfconsciously deploying the language of theatricality in her fiction in order to critique the artificiality of the bon ton. ${ }^{22}$ In The Manners of the Day, she compares Helen Willersdale's initiation into exclusive society to the experience of uncovering the hidden workings of the stage:

Were any person entering a theatre for the first time, to find himself introduced behind the scenes, rather than into the area of audience, he would be at once deprived of all the pleasures arising from dramatic illusion. He would be impressed by the coarseness of the bedaubed scenery-by the laborious efforts of the machinery - by the tinselled frippery of the dresses and decorations - by the hollowness and superficiality of the whole affair. (I, p. 43)

In Pin Money, too, the language of the theatre is used to convey the synthetic character of the dinner parties habitually attended by the exclusive Calder set: 'all the stage-trick of artificial life was $[\ldots]$ familiarly known to them,- the wooden trap-doors of the pantomime were [...] glaringly apparent to their experienced eyes'. ${ }^{23}$ In The Hamiltons, by contrast, naïve newlywed Susan Hamilton is initially enchanted by the spectacular 'round of feasting and frivolity' she encounters in high society, as she knows 'nothing of the traps and pullies and

\footnotetext{
${ }^{22}$ William Makepeace Thackeray, Vanity Fair, ed. by J. I. M. Stewart (London: Penguin, 1985), pp. 33-34.

${ }^{23}$ Catherine Gore, Pin Money; A Novel, 3 vols (London: Henry Colburn and Richard Bentley, 1831), II, p. 184 (original emphasis). All subsequent references are to this edition, incorporated in the text with pagination in parentheses.
} 
mechanical business of the stage' (p. 109). Like Helen in The Manners of the Day, Susan has been brought up outside of the rarefied confines of the fashionable world but, after marrying into an eminent political family, she quickly comes to realize that she must learn to "play [her] part' within it (p. 98). Archetypes of a new class of powerbrokers who are not of noble birth, the Hamiltons use orchestrated displays of festal grandeur to consolidate their political influence. Susan's husband Augustus thus makes clear to her that on social occasions 'her cues must be properly minded, and the business of the stage carefully rehearsed' (p. 98).

References to stagecraft similarly permeate the social instruction manuals of the 1830s, where dinner parties are typically represented as scripted, ritualistic performances. In her 1835 handbook The English Housekeeper, Anne Cobbett writes:

A fashionable dinner is arranged as follows. Candles, plateau, epergne or vases, in the centre of the table: two soups, one at each end, and these removed by two dishes of fish; little patties down the sides: the sauces for the fish not put on the table, but handed round, from the sideboard. ${ }^{24}$

These abbreviated instructions have the air of stage directions, the objects and foodstuffs listed functioning as props for the display of tastefulness. Like a theatrical performance, the 'fashionable dinner' is iterative in character and carefully obscures the behind-the-scenes labour involved in its production. Natalie Kapetanios Meir observes that Cobbett's use of the passive voice subtly elides the subjects doing the handing round and removing, implying that such work is 'performed invisibly', while the reference to candles, etc. 'in the centre of the table' makes it seem as though the objects simply appear there of their own accord, 'customarily' and 'without human agency'. ${ }^{25}$

This idea of automatic functioning also emerges in The Manners of the Day when Helen attends a dinner party hosted by her elegant sister-in-law, Lady Danvers. Accustomed to the old-fashioned country dinners of her parents' circle, where the emphasis is on

\footnotetext{
${ }^{24}$ Anne Cobbett, The English Housekeeper: or, Manual of Domestic Management (London: Anne Cobbett, 1835), p. 51.

${ }^{25}$ Natalie Kapetanios Meir, “'A Fashionable Dinner is Arranged as Follows”: Victorian Dining Taxonomies', Victorian Literature and Culture, 33 (2005), 133-48 (p. 138).
} 
profusion rather than finesse, Helen is entranced by the seemingly effortless sophistication of the Danvers feast: 'the whole affair of the table was conducted by almost invisible machinery; the most exquisite viands dispersed with noiseless assiduity' (I, p. 96). The narrative focus on the meal's aesthetic appeal and seamless execution encourages us to read it as an exemplar of tastefulness, a literary version of the idealized dinner parties conjured in nineteenth-century etiquette guides. However, the reference to 'machinery' in the above quotation undercuts this impression, divesting the occasion of some of its allure by hinting that its conspicuous refinement is a matter of perfunctory routine, mechanically performed. What is more, via the qualifying phrase 'almost invisible', Gore indicates that the spectacular dinner party does not simply happen, as if by magic; rather, the carefully curated event is contingent on the unacknowledged labour of a staff of anonymous servants for its smooth running and veneer of elegance. ${ }^{26}$

The mechanization that underpins individual dining events in Gore's fiction extends to her representation of 'the season', the annual London gathering of fashionable society. In a number of novels, the routinized quality of this focal point in the aristocratic calendar finds its echo in the iterative narrative techniques used to describe it. In Pin Money, for instance, the season comprises a series of 'balls,- - both fancy and matter-of-fact,- - concerts,- - dinnerparties,- - water-parties,- - breakfasts,_-and picnics', which are 'successively hailed in prospect, yawned over in endurance, and apostrophized as charming on the following week' (III, pp. 6-7). In The Manners of the Day, likewise, the season is synopsized as 'a ceaseless but varying succession of dinners, balls, concerts, déjeuners, and water-parties; of waterparties, déjeuners, concerts, balls, and dinners' (I, p. 137), Gore's use of chiasmus underlining the highly patterned character of its constituent activities.

\footnotetext{
${ }^{26}$ The illusion of automatic functioning is further punctured in The Manners of the Day when the narrator observes that, 'It is strange how a single occurrence, apparently so simple in cause and effect as a dinner [...] can occupy the invention and labour and anxieties of a whole legion of human beings!' (III, p. 108).
} 
Perhaps unsurprisingly, Helen Willersdale is distinguished from the majority of the beau monde by her distaste for the formulaic entertainments of the season:

[S]he seemed to shrink from [...] the thousand and one balls which, during the merry month of May, serve to congregate the self-same five hundred faces, in divers streets and squares of the more civilized parishes of the metropolis; and not unfrequently to exhibit the self-same Gunterian tongues and chickens upon their successive supper-tables. (III, p. 234-35)

Once again, here, the use of iterative narration highlights the contrived, mechanical character of the London season. As Cheryl Wilson notes, the image constructed in Gore's fiction is 'of an assembly-line society' in which the members of the ton function as 'automata, performing predetermined movements'. ${ }^{27}$ Within this orchestrated world, things that should constitute signs of distinction — in this case, a series of dishes supplied by the sought-after cateringfirm Gunter's — instead come to symbolize homogeneity, their ubiquity attesting to the craven conventionality of peremptory canons of taste. Indeed, the ambiguous status of the exclusive-but-commonplace 'Gunterian tongues and chickens' highlights one of the central problematics that troubles the silver-fork novel's representation of class-based distinction. If 'good taste' is socially constructed rather than natural and achieves validation through iterative performance or display, then its visible signifiers (bodily practices, material artefacts and so on) are vulnerable to appropriation and imitation by those who aspire to exclusivity. By mimicking physical behaviours and co-opting relevant cultural objects, ambitious parvenus are able to disrupt classificatory processes and subvert the ideology of intrinsic tastefulness that maintains the social elite's discretionary power.

A minor sub-plot in Gore's Mothers and Daughters makes clear the danger posed to the established order by such acts of emulation. Lady Radbourne is initially introduced to readers as a social climber utterly lacking in discrimination, a woman ridiculed by existing members of the ton for repeated 'breaches of the peace of fashion', such as serving 'iced

\footnotetext{
${ }^{27}$ Cheryl A. Wilson, Fashioning the Silver Fork Novel (London and New York: Routledge, 2016), p. 37.
} 
claret and hot sauterne for the suppers of her provincial balls'. ${ }^{28}$ By the end of the text, however, Radbourne has risen to the position of patroness of Almack's assembly rooms, an influential role that confers on her quasi-despotic powers as an arbiter of taste. Her newfound distinction is signalled by her conspicuously late arrival at the fashionable dinner parties to which she is now invited, her tardiness working to increase the evidence of her importance' (p. 356), demonstrating Bourdieu's point that 'one's relationship to the social world $[\ldots]$ is never more clearly expressed than in the space and time one feels entitled to take from others' ${ }^{29}$ This salutary lesson in the permeability of ostensibly rigid hierarchies indicates that the codified norms that surrounded aristocratic social experiences in the $1830 \mathrm{~s}$ were far from invulnerable to incursions from below. Although these culturally constructed conventions were designed to function as the gatekeepers of exclusivity, their performative character could, ironically, facilitate emulative behaviours and thus expedite social mobility.

\section{Taste and Gender}

The performance of social ritual in the early nineteenth century was closely imbricated with the performativity of gender. Denise Gigante notes that as the class boundaries that had long served to demarcate tastefulness became increasingly blurred, 'gender lines acquired heightened significance as markers of sophistication' ${ }^{30}$ At the fashionable dinner table, this increased investment in gendered codes of distinction gave rise to differently focused expectations for men and for women: whereas the former could prove their fine aesthetic judgement by engaging with the principles of gastronomy-a quasi-philosophical discourse

\footnotetext{
${ }^{28}$ Catherine Gore, Mothers and Daughters; A Novel (London: Richard Bentley, 1834), p. 169. All subsequent references are to this edition, incorporated in the text with pagination in parentheses.

29 Bourdieu, p. 476.

${ }^{30}$ Denise Gigante, Taste: A Literary History (New Haven and London: Yale University Press, 2005), p. 174.
} 
that sought to '[elevate] food to the status of the fine arts' ${ }^{31}$ - the latter were expected to demonstrate refinement via conspicuous displays of alimentary delicacy or, in certain circumstances, the total repudiation of bodily appetite. As with the social codes discussed earlier, these cultural conventions are reiterated but also lampooned in Gore's writing. While engaging with the gendered mores that structured nineteenth-century dining experiences, Gore's fictions additionally highlight their status as contrived mediators of social privilege and civility: sophistications of the basic act of eating that never entirely succeed in masking the crude physicality of consumption.

Since antiquity, gustatory taste has been categorized as one of the 'lower' bodily senses, and contrasted with the 'higher' aesthetic faculties of vision and hearing. As Carolyn Korsmeyer explains, in the Western intellectual tradition 'the degree to which the body is experienced as involved in the operation of the senses' affects their hierarchical classification. ${ }^{32}$ Whereas, in the case of sight, the object of vision remains detached from the organ that perceives it, 'taste requires perhaps the most intimate congress with the object of perception', and thus, historically, has been denigrated as troublingly carnal, the locus of somatic rather than cerebral gratification. ${ }^{33}$ For this reason, philosophers such as Immanuel Kant have attempted to distinguish the 'pure' aesthetic taste associated with vision from the comparatively vulgar, subjective taste associated with the palate. Indeed, in a brief but telling aside in Anthropology From a Pragmatic Point of View (1797), Kant expresses bewilderment that modern languages should have come to designate the elevated power of aesthetic judgment by a term 'that refers merely to a certain sense organ (the inside of the mouth) and to the way we use this organ to distinguish, as well as to choose, things we can enjoy'. ${ }^{34}$

\footnotetext{
${ }^{31}$ Gigante, Taste, p. 1.

${ }^{32}$ Carolyn Korsmeyer, Making Sense of Taste: Food and Philosophy (Ithaca and London: Cornell University Press, 1999), p. 3.

${ }^{33}$ Korsmeyer, p. 3.

${ }^{34}$ Immanuel Kant, Anthropology from a Pragmatic Point of View, trans. by Mary J. Gregor (The Hague: Martinus Nijhoff, 1974), p. 110.
} 
With the emergence of the field of gastronomy in the early nineteenth century, however, gustatory taste acquired newfound legitimacy as a signifier of aesthetic discrimination. Gigante observes that 'just as the eighteenth-century Man of Taste had sought to distinguish nicely between different qualities of beauty', the pioneers of gastronomy 'emphasized empirical exactitude and objective discernment in parsing the different flavours of food'. ${ }^{35}$ Connoisseurs in the art of fine dining, gastronomes were keen to differentiate themselves from mere gluttons. The author of one gastronomic tract takes pains to point out that the genuine epicure or gourmand is no mindless overeater, but rather the epitome of sagacity and refinement; possessor of 'a delicate susceptibility in the organs of degustation', he is set apart from the mass of consumers by his finely cultivated ability 'to appreciate the true relish of each ingredient' in even the 'most compound ragoût'. ${ }^{36}$ This specialization in matters of the palate comes to fulfil an honorific function, according to the late-nineteenthcentury sociologist Thorstein Veblen; furnishing evidence of both wealth and sensory judgement, 'punctilious discrimination [...] in eating [and] drinking' becomes an important signifier of leisured masculinity. ${ }^{37}$

In Gore's silver-fork novels, the role of discerning gastronome is fulfilled most prominently by Lord Danvers in The Manners of the Day. A philosopher of haute cuisine, Danvers' conversation revolves almost exclusively around esoteric culinary topics such as 'the Marmite perpétuelle', and 'the Frères Provencaux and their Huitres à l'estragon', while, as a 'discriminating patron' of the gastronomic arts, his support for the production of edible 'chef-d'œuvre[s]' equals that of 'the Borghesi' for 'the master-pieces of Raphael' (I, pp. 101, 93). His 'personal devotion' to gastronomy is further demonstrated via the tributary

\footnotetext{
${ }^{35}$ Denise Gigante, Gusto: Essential Writings in Nineteenth-Century Gastronomy (New York and London: Routledge, 2005), p. xx.

${ }^{36}$ Launcelot Sturgeon, Essays Moral, Philosophical, and Stomachical, on the Important Science of Good-Living (London: G. and W. B. Whittaker, 1823), p. 4.

37 Thorstein Veblen, The Theory of the Leisure Class, ed. by Martha Banta (Oxford: Oxford University Press, 2007), p. 53.
} 
'hecatombs' (I, p. 92) offered up at Danvers House. This classical allusion not only establishes a link between Danvers' entertainments and antique civilization (in Greece and Rome, a hecatomb was a sacrifice of a hundred oxen), but also indicates that his dinner parties can be read as exercises in conspicuous consumption. As Veblen suggests, lavish feasts make manifest the affluence and discrimination of the host by demonstrating that 'he consumes freely and of the best', while co-opting fellow diners into this spectacular display of prestige: the guest 'consumes vicariously for his host at the same time that he is witness to the consumption of that excess of good things which his host is unable to dispose of singlehanded' ${ }^{38}$ Profusion at table becomes a yardstick of masculine aristocratic distinction; yet, problematically, it also enables the kind of gluttonous consumption that was ostensibly disowned by nineteenth-century gastronomes.

Lord Danvers' dietary habits certainly trouble the precarious divide between gluttony and gourmandism. His feats of gastronomic connoisseurship during the season result in him doing 'penance' (I, p. 92) for the remaining six months of the year with gout, an illness more usually associated with alimentary excess than with refined appetite. A similar fate is suffered by other male gourmands in Gore's oeuvre. In Mothers and Daughters, Sir George Wolryche's 'crutches and flannels' - conventional symbols of a gouty constitution-'do melancholy honour to the ministry of the immortal Ude' (p. 461), a famous Regency chef. Further, in the short story 'A Manœuvrer Outwitted', animal imagery is used to signal the base hunger of ostensibly sophisticated epicures: Lord Dotterel is compared to a ravenous 'creature at feed;- - his eyes glistening, and his lips quivering!' and his companions to 'so many hounds round the boiler in a kennel kitchen' (Sketch Book, III, pp. 128, 127). Such bathetic references to bodily morbidity and animal appetite puncture discursive efforts to equate gustatory with aesthetic judgement and to elevate gourmandism to a fine art. If

\footnotetext{
${ }^{38}$ Veblen, pp. 52, 53-54.
} 
nineteenth-century gastronomy sought to civilize and aestheticize the act of masculine consumption, Gore's works ironize this process of sublimation, anchoring gustatory taste firmly within the realm of the somatic and challenging its status as a marker of cultivation.

Whereas gourmandism functions as a (contentious) symbol of male distinction in representations of exclusive society, for women it is conspicuous non-consumption or ostentatious frugality that signifies tasteful behaviour. Indeed, a hearty female appetite is configured as both vulgar and grotesque in Pin Money, where the socially ambitious Mrs Waddlestone ('a fat middle-aged woman' (I, p. 97)) is ridiculed variously as a monstrous 'Odalisque' (I, p. 98) and 'the animated image of a colossal Cantelupe [sic] melon' (I, p. 306). Her obesity contrasts with the dainty appetitive delicacy of Lady Launceston, mother of the novel's heroine Frederica, who is distinguished by her fastidious tastes and limited ingestion. Although, in keeping with the demands of fashionable society, she ensures that her guests are supplied with elegant French dishes such as filet de caneton and fromage plombière when they dine at her London home, Lady Launceston carefully restricts her own consumption to plain foods such as 'boiled chicken' and 'toast and water' (I, p. 133). An inveterate hypochondriac, she supplements her insipid diet with a range of demulcents, expectorants and balsamics, including juleps, arrowroot, chocolat de santé, peppermint drops and tolu lozenges. This semi-medicinal regimen bespeaks a scrupulous concern for what enters and assimilates with the body, categorizing Lady Launceston as a woman of distinction for, as Bourdieu suggests, the way in which one treats the body, cares for it, feeds it and maintains it makes visible 'the deepest dispositions of the habitus' ${ }^{39}$ In particular, the 'disposition to discipline food consumption'-something 'quite different from enforced privation'-works to classify the subject by communicating her social privilege: the

\footnotetext{
${ }^{39}$ Bourdieu, p. 188.
} 
discriminating consumer does not eat frugally out of necessity, but rather from choice, in order to exhibit her good taste. ${ }^{40}$

Lady Launceston's 'elegant valetudinarianism' (II, p. 86) can thus be understood as a form of sophistication: a complex use of simple fare. Ironically, her preferred foods - tea and toast - are also staples of the working-class diet in the early nineteenth century. Crucially, though, her stylized manner of consuming them-her tea is served in a 'small covered basin of Dresden china', while her 'dried toast' is cut into 'two taper sticks' (I, p. 60)—makes clear her distinction. Gore satirizes this sophisticated use of basic foods, just as she derides the gluttony that underlies male gourmandism. Notably, her work contains a number of marginal references to hunger and poverty, which, though cursory, hint subtly at the disingenuousness of Lady Launceston's appropriation of a proletarian diet. Whereas the distressed 'manufacturing classes' (II, p. 144), 'poor widow[s]' and 'starving labourer[s]' (III, p. 6) fleetingly conjured in Pin Money are presumably obliged to subsist on plain and scanty provisions, Lady Launceston's restricted regimen is a lifestyle choice, one that signals her dislocation from the material realities of deprivation. As Gore's narrator notes, 'the tissue of fashionable life' may be of a 'flimsy and artificial' texture, but it nevertheless insulates the upper classes from 'the pangs of hunger' and 'a belief in the tangible existence of want' (III, p. 189).

Younger women of taste in Gore's novels tend to be associated less with the 'elegant valetudinarianism' exhibited by Lady Launceston and more with alimentary abstention, particularly at times of emotional distress and/or romantic disappointment. This representational trend draws on the conventions of the late eighteenth- and early nineteenthcentury sentimental novel, in which the motif of the abandoned or betrayed heroine who enters into a gradual decline is 'ubiquitous', as Claudia Johnson suggests, and 'wasting away

\footnotetext{
${ }^{40}$ Bourdieu, p. 194.
} 
is almost a matter of good grace'. ${ }^{41}$ While nodding to this literary tradition, Gore also parodies it, highlighting the farcicality of a social tenet that compels women to starve themselves in order to appear tasteful. When it seems as though Sir Brooke Rawleigh, the stolid hero of Pin Money, is about to transfer his affections from Lady Frederica to Laura Mapleberry, Lady Launceston and her apothecary look forward to 'the gratifying excitement of an indefinite and highly-promising indisposition' (I, p. 13). However, Frederica proceeds to defy both parental and literary expectations: 'after taking torrents of camphor-julep', she '[takes] courage' (I, p. 13) and embarks on her own flirtation with Colonel Rhyse, a bold tactic that revives Sir Brooke's interest and elicits a proposal from him within a week. In a further subversion of the gendered conventions that typify the early nineteenth-century novel, it is Sir Brooke who then goes on to demonstrate the kind of emotional eating-behaviour more usually associated with the sentimental heroine. Plagued by suspicions of Frederica's infidelity, Sir Brooke repeatedly rejects the food that is offered to him: at breakfast, he cannot 'be persuaded to sit down to his tea and French rolls', despite being 'guiltless of any food more substantial than a biscuit' since the previous day (II, p. 6), and later he feels only 'nausea' when served with a bowl of smoking spring-soup at his club (II, p. 45).

The literary convention of the romantically betrayed heroine who subsequently wastes away is again satirized by Gore in the humorous short story 'My Place in the Country'. When Richard Martindale suddenly announces that he intends to visit relatives in Hertfordshire, his wife Mary-Matilda hysterically imagines that he is in fact departing for an adulterous assignation. Determined to punish Richard for his perceived infidelity, Mary-Matilda resolves to engage in a kind of appetitive martyrdom: to 'lie on the sofa [...] and sentimentalize herself into languor', in hopes that, when her truant husband returns, he shall find her 'looking as pale as the cambric handkerchief she now incessantly applied to her

\footnotetext{
${ }^{41}$ Claudia L. Johnson, Jane Austen: Women, Politics, and the Novel (Chicago and London: University of Chicago Press, 1988), p. 65.
} 
eyes' (Sketch Book, I, pp. 201-02). However, 'playing the victimized invalid' turns out to be rather less satisfying than she had anticipated (I, p. 202). After spending five tedious days 'picturesquifying in her dressing gown', the 'half famished' Mary-Mathilda finally tires of her prolonged abstinence and orders a supper-tray to be sent to her room. To her horror, though, just as she has 'filled her plate with a provision of cold lamb and sallad [sic] enough to have dined a corporal of dragoons', Richard returns home, shattering the illusion of tasteful decline she has worked so hard to cultivate (I, p. 202).

By attesting to the power of female appetite, this comical narrative challenges the literary stereotype of the ethereal woman and exposes the absurdity of the ideology of elegant attenuation at work in sentimental fiction. Elsewhere though, Gore offers a more serious critique of nineteenth-century gender values, demonstrating that their cultural pervasiveness and creeping naturalization can have pernicious effects. When Claudia Willingham, one of the husband-hunting daughters in Mothers and Daughters, is rejected by the Duke of Lisborough, her close friends and family express disquiet about her loss of appetite and emaciated form. Lady Barringhurst, however, dismisses their concerns, maintaining that 'every girl grows thin at the close of the season', as 'living from April till July on sighs and syllabubs, hope and sponge biscuits is a bad regimen to encourage enbonpoint' (p. 219). The conflation, here, of Claudia's emotionally motivated food refusal with the reducing diets of fashionable young socialites highlights - and implicitly critiques - the way in which exclusive society normalizes pathological eating behaviours among women. A counterpoint to the comic subversion of social convention in Pin Money and 'My Place in the Country', Mothers and Daughters takes a more sober stance on gendered norms of consumption, exposing the dangers of too close an adherence to established codes, and tacitly condemning an ideology of tastefulness that virtually compels women to be ill. 


\section{Spaces of Consumption}

If the dining-room is, as Muireann O'Cinneide contends, one of the 'quintessential narrative spaces' in silver-fork fiction, it is in part because of its crucial role in bringing together male and female characters. ${ }^{42}$ In The Manners of the Day, Gore humorously suggests that 'a meal of any description, is a domestic crisis which alone appears to justify, in Great Britain, the reunion of the sexes' (II, pp. 89-90), her assertion echoing silver-fork novelist Theodore Hook's point that the dining-room is 'the point de réunion' of every aristocratic circle, for 'the bashful Englishman and the timid Englishwoman are never so much at their ease as when sitting round a table'. ${ }^{43}$ The dining-room thus has a cohesive social function, uniting male and female subjects who share a particular habitus: notably, it is during a dinner that Lord Willersdale first recognizes Helen Mordaunt as a woman who shares his own intuitive good taste and falls in love with her. While bringing subjects into a 'community of identification', however, the dining-room also 'divides them', segregating them from the mass of the uninvited. ${ }^{44}$ One of the so-called 'public rooms' of the house, designed for the reception of guests, the nineteenth-century dining-room is also a private, privileged space, inaccessible to outsiders. Its dual character is shared by 'taste', which likewise unites even as it separates, bringing together 'those who are the product of similar [class] conditions while distinguishing them from all others'. ${ }^{45}$ Given this affinity, it is perhaps unsurprising to find that ideologies of taste are closely allied to the spatial politics of inclusion and exclusion in silver-fork novels, facilitating determining judgements about who may or may not be admitted to the table.

\footnotetext{
${ }^{42}$ O’Cinneide, p. 51.

43 Theodore Hook, quoted in Adburgham, p. 50.

${ }^{44}$ O’Cinneide, p. 14.

${ }^{45}$ Bourdieu, p. 49.
} 
Despite the care with which the boundaries of exclusivity are policed in silver-fork writing, the dining-room is recurrently the scene of what Winifred Hughes terms 'border skirmishes' between the social elite and middle-class parvenus. ${ }^{46}$ Spaces of consumption are presented as particularly vulnerable to incursions by wealthy social climbers. Indeed, the prospect of a cross-class dining encounter is a common source of anxiety in Gore's fiction. In Mothers and Daughters, for instance, the Willingham sisters are horrified when their uncle General de Vesci (a man rich in pecuniary resources but deficient in ton) announces his intention to invite the distinguished Duke of Lisborough to dinner. Similarly, in The Hamiltons, Augustus Hamilton is aghast when it appears that his wife Susan has committed them to dine with the arriviste Burtonshaws, a family he dismisses as 'showy-looking English people', 'over-dressed [and] under-bred' (p. 143).

In both of these cases, the possibility of class commixture is ultimately averted, as the coveted guests refuse their invitations. Elsewhere in Gore's fiction, though, the ambitious middle classes succeed in luring the social elite to their dinner tables. In The Manners of the Day, Helen Willersdale agrees to dine with the Forsyths, 'a set of vulgar tuft-hunting people' (II, p. 99), at their Harley-Street home, while in Pin Money, Sir Brooke and Lady Frederica Rawleigh are inveigled into attending a fête hosted by Mrs Luttrell, a woman 'strictly confined within the limits of mediocratic society' who lives 'somewhere at the antipodes, - in the Regent's-park' (I, pp. 96, 82). The non-exclusive setting of both these evening parties is significant: as Edward Copeland points out, silver-fork novelists imagined 'Mayfair and Marylebone as opposing social and political forces', aligning the former with the established aristocracy and the latter with 'nabobs, the newly titled, the newly rich and the successful professional ranks'. ${ }^{47}$ In the end, though, it is the topography of the Luttrell and Forsyth dining-rooms, rather than the geographic location of their houses, that most clearly

\footnotetext{
${ }^{46}$ Hughes, p. 331.

${ }^{47}$ Copeland, pp. 130-31.
} 
communicates the vulgarity of their hosts. Mrs Luttrell's 'house of feasting' is depicted as a temple of artifice and pretension: the walls have been decked with 'withering laurelbranches' in an effort to renovate the space as a 'rural retreat' (I, p. 95); the uncouth 'gang' of servants hired for the occasion have been dressed in 'glaring', ill-fitting livery (I, p. 95); and the supper-room itself '[savours] horribly of ham sandwiches and negus', its sickly aroma combining with the gaudy glitter of 'caramel baskets and pyramids of foil' (I, p. 103) to create an impression of ocular and olfactory excess.

The portrayal of the Forsyth dinner party works similarly to ratify the old adage that money can't buy taste. The family's dining-room is crammed with a glut of visual signifiers designed to communicate affluence and discernment: a pair of gilt candelabra and matching dessert service from Rundell and Bridge, affixed with the newly commissioned Forsyth shield ('one of the most elaborate and mendacious imaginations of the Herald's College' (III, p. 108)); 'gilded salvers', fresh from the furnace (III, p. 109); and a cornucopia of gourmand dishes crafted by the celebrity chef Louis Eustache Ude, including glacéed cockscombs in pomegranate juice, rabbits' tongues stuffed with pistachios, sautéed capons' livers and larks' thighs. Despite - or rather because of - this flagrant display of opulence, 'all [is] wrong' with the occasion (III, p. 131). As Bourdieu suggests, exhibitionism is the marker of the nouveau riche who “"overdoes it”, betraying his own insecurity', whereas culturally legitimized taste is characterized by 'a sort of ostentatious discretion, sobriety and understatement, a refusal of everything which is "showy", "flashy" and pretentious, and which devalues itself by the very intention of distinction' ${ }^{48}$ In this light, the excessive middle-class dinner party can be seen to serve a structural as well as a comic purpose in Gore's fiction, re-emphasizing the 'natural' refinement of her heroines, whose simple tastes are thrown into relief by the affected, overextravagant spaces of consumption in which they find themselves.

\footnotetext{
${ }^{48}$ Bourdieu, p. 246.
} 
Gore's insistent mockery of bourgeois efforts to emulate aristocratic dining-styles has, unsurprisingly, led critics to identify her fiction with an essentially conservative politics. Certainly, her novels tend overtly to endorse traditional hierarchies while rejecting class mobility, a stance encapsulated in the mea culpa of one repentant social climber: 'let us return to the mode of life for which we were born, and which suits us best' ('My Place', Sketch Book, I, p. 55). When it comes to the politics of taste, however, Gore tentatively adopts a more egalitarian outlook, occasionally conceding that aesthetic discrimination is not the exclusive preserve of the social elite. When, in Pin Money, Mr Waddlestone- a former barrister who has married into a wealthy family of soap manufacturers — arranges a breakfast at his home in Kensington Gore, 'all that opulence and purity of taste could effect was visible in its arrangements' (III, p. 228). The select party of guests is invited, first, to feast their eyes on the exquisite Italian artworks that decorate his house (the elegant arrangement of which induces the snobbish Lord Calder to express astonishment at seeing the arts 'fostered with feeling and judgment by—a soapboiler!' (III, p. 244)) and then to sate their appetites in the 'almost regal banquetting-room' (III, p. 262). Here, 'the more than epicurean daintiness of the feast, and the brilliant flow of conversation by which it was enhanced' help to classify the Waddlestone breakfast as a paradigm of good taste (III, pp. 262-63), its restrained elegance contrasting with the obtrusive display and sham pageantry of the Forsyth and Luttrell fêtes.

Importantly, though, if middle-class spaces of consumption can in certain circumstances conform to silver-fork ideals of tastefulness, then aristocratic eating-spaces can, reciprocally, become sites of vulgarity or indelicacy. Although governed by inflexible codes and strictures, the fashionable dining-room in Gore's fiction is not impervious to displays of tastelessness or indiscretion. Michel de Certeau's distinction between 'place' (lieu) and 'space' (espace) is significant here: whereas the former is associated with stability, rules and "the law of the "proper", the latter "is composed of intersections of mobile 
elements' and is thus both contingent and multivalent. ${ }^{49}$ If the dining-room as idealized place is ruled by the laws of etiquette, the dining-room as inhabited space is vested with the possibility of contravention or transgression. Just as 'the street geometrically defined by urban planning is transformed into a space by walkers', so the nineteenth-century diningroom is transformed by the diners who eat, drink and converse there. ${ }^{50}$ When, for instance, the Duke of Lisborough and his wife give a dinner party in Mothers and Daughters the initial indications are that it will be a tasteful affair (the Lisborough mansion is a place of aesthetic splendour and the guest-list suitably select). Yet when the assembled company actually inhabits the dining-room, the distribution of bodies within the space produces an air of discord and disunity. The 'banquets of the great' are typically regulated by established rules about who sits where, the 'rank of the guests' being 'too peremptory a claim to be waived' (p. 406). However, by means of some 'obstinate manoeuvring', Charles Willingham manages to 'station himself by the side of Miss de Vesci' (p. 406), the object of his affections, and this disruption to dining-room etiquette results in no one being seated where they had anticipated. In contrast to the Waddlestone breakfast, the table-talk at the Lisborough dinner fails to scintillate or effervesce, and the whole occasion is marked by a sense of disaffection and estrangement. As the narrator concludes, 'such are the contre-temps of a dinner-party composed of ill-assorted persons!' (p. 409).

The impression that things are not quite comme il faut similarly mars the Ebury Hill fête in Mothers and Daughters. Although the setting is elegantly appointed, suggesting a superficial tastefulness, the behaviour of the participants on the day transforms the space into one of tawdry impropriety. Lord Cosmo Somerset neglects his duties as host in order to flirt with Mrs Grandison, leaving the oblivious Mr Grandison to preside over lunch in his

\footnotetext{
${ }^{49}$ Michel de Certeau, The Practice of Everyday Life, trans. by Steven Rendall (Berkeley: University of California Press, 1984), p. 117.

${ }^{50}$ De Certeau, p. 117.
} 
absence. When the refractory lovers finally emerge in the dining-tent, they unashamedly 'whisper over their maraschino, and break mottoed bonbons for each other's gratification, with as much exclusive self-engrossment as if they only had inhabited the marquee' (p. 246). The fête is further replete with the kind of vulgar excess typically found in the parvenu dining-room, albeit on a more extravagant scale: the grounds have been laid out in the style of a Tyrolean village; there are fireworks and jets d'eau for the amusement of the guests; and the refreshment tent is adorned with a variety of 'saccharine glories', including a 'caramel temple, enwreathed with pistachio laurels, and crowned with roses of melting marmalade', and spun-sugar reconstructions of the Bastille and Trocadero, the work of four French confectioners hired especially for the occasion (p. 258). Despite such obvious efforts to impress, the fête stands accused of diverse breaches of taste: Lady Rachel Verney and her circle sneer that the claret is too hot, the soup too cold and the attendants ungloved and grimy-handed. Ironically, these complaints are themselves symptomatic of the tastelessness that suffuses the event for, as Leigh Hunt suggests, 'attacks on vulgarity' are themselves often 'of the vulgarest description'. 51

While encouraging readers to critique the ostentation of the Ebury Hill fête, Gore does acknowledge the allure of such dazzling social spectacles. Indeed, one of the most frequently deployed images in her fiction is that of the season as intoxicant. ${ }^{52}$ Ultimately, though, Gore's novels tend to culminate in a strategic withdrawal from fashionable spaces of consumption and a relocation to the unpretentious sphere of the domestic dining-room. This divestment from the beau monde is particularly evident in Pin Money, where newlyweds Sir Brooke and Frederica Rawleigh come to value the intimacy of homely eating-spaces over the finery of fashionable society. In fact, Frederica has always had a natural 'taste for the domesticities of private life' (III, p. 49) and would have been content 'to pass the first spring of her married

\footnotetext{
${ }^{51}$ Leigh Hunt, The Autobiography of Leigh Hunt, with Reminiscences of Friends and Contemporaries, 3 vols (London: Smith, Elder and Co., 1850), II, p. 25.

${ }^{52}$ See, for instance, Gore, Manners, I, p. 136.
} 
life' in the rural seclusion of her husband's Rawleighford estate (I, p. 45). However, spurred on by her false-friend Louisa Erskyne, who bemoans the 'dullness of domestic life', Frederica immerses herself in the modish entertainments of Regency London (I, p. 50). Sir Brooke, meanwhile, decides that it is incumbent on a man of his status to stand for Parliament, despite his patent unsuitability for the role, and as a result spends much of his time away from home, canvassing at political dinners. The frequency with which the Rawleighs dine apart is generally seen as evidence of their voguishness: one observer comments that they are 'quite a fashionable couple' who live separately 'as people of ton and the figures on a Dutch weather-glass ought to do' (II, p. 294). In actuality, though, their segregated consumption engenders marital discord which is only resolved at the end of the text when the couple reject fashionable spaces of consumption-picnics at the races, exclusive supper-parties and Sir Brooke's London club-for the commensal pleasures of home. Tellingly, Pin Money ends with a 'delightful' (III, p. 323) family dinner that is presented to readers as more genuinely tasteful, in its sociability and lack of affectation, than all of the 'magnificent collation[s]' (II, p. 52) that have preceded it.

While censuring the emulative behaviours of middle-class social climbers, then, Gore tacitly endorses the embourgeoisement of the aristocracy by advocating the upper-class espousal of domestic ideals. This promotion of middle-class values has implications for the silver-fork novel itself as a space of consumption. As a number of critics have noted, anxieties about the literary tastes of middle-class readers abounded in the early nineteenth century: Gigante cites Wordsworth's complaints regarding the 'fickle appetites' of the reading public and Coleridge's grumbles about the 'vulgar' inclinations of those who 'dieted' at the 'ordinaries of Literature, the circulating libraries', in support of her claim that 'the danger was always the potentially "bad" taste of the economically empowered consumer'. ${ }^{53}$

\footnotetext{
${ }^{53}$ Gigante, Taste, pp. 15-16.
} 
Within this metaphorics of reading-as-consumption, the silver-fork novels that flooded the literary marketplace in the 1830s were perceived as particularly unhealthy fare. An 1831 article in Blackwood's Edinburgh Magazine condemned as 'gross' and 'vulgar' the 'overgorged and yet insatiable' public appetite for 'Tales of Fashionable Life', while a review in Fraser's Magazine in the same year expressed hopes that audiences would 'no longer stomach' the 'trashy' output 'which Messrs. Colburn and Bentley' (the leading publishers of silver-fork fiction) had 'for many a long year [...] thrust down the gullable [sic] throats of the British public'. ${ }^{54}$

Gore, however, challenges the idea that fashionable fiction is merely 'a tissue of puerile vulgarity' (Manners, II, p. 235), trusting to her middle-class readership to intuit the difference between showy pretension (the object of her satire) and genuine tastefulness (the object of her approbation). Although she continues to invest in the idea that some subjects are gifted with 'natural distinction' - a notion that had long served the aristocracy's selfpresentation as the legitimate custodians of good taste-Gore's works also ironize and denaturalize the codes and conventions by which such cultural authority is maintained. Indeed, by disaggregating ideas of 'taste', 'fashionability' and 'status' - by attributing 'natural distinction' to unworldly genteel heroines and hinting that dandies and nobles are as capable of vulgarity as those outside the peerage or uninitiated in ton-Gore creates a space for members of her 1830 s readership to exercise their own powers of discrimination, recalibrating, if not quite democratizing, the relationship between taste and class.

\footnotetext{
54 'Noctes Ambrosianæ', Blackwood's Edinburgh Magazine, 30 (1831), 531-64 (p. 536); 'The Novels of the Season - Batch the Second', Fraser's Magazine for Town and Country, 4 (1831), 8-25 (p. 11).
} 